\title{
ЕЛЕМЕНТИ ТЕОРІЇ ПЕРЕТВОРЕННЯ СЛІДУ КОНТАКТУ КОЛІСНОГО РУШІЯ АВТОМОБІЛЯ 3 ОПОРНОЮ ПОВЕРХНЕЮ В ГОЛОВНИЙ МОМЕНТ СИЛ ІНЕРЦІЇ СТИСНУТОЇ ЧАСТКИ ШИНИ
}

\author{
Петров Л. М., Скоріченко О. I.
}

\section{ВСТУП}

Велика роль у піднятті працездатності в перевезені великих об'ємів вантажів відводиться новим потужним вантажним автомобілям. Нові вантажні автомобілі повинні мати підвищену енергонасиченість та працювати на більш підвищених швидкостях. Для цього необхідно відпрацювання конструктивних розробок нових технологічних рішень, а також обгрунтування основних параметрів, які пов'язані з коченням колісного рушія автомобіля ${ }^{1}$.

Під час взаємодії ходової частини вантажного автомобіля з грунтом він деформується. Деформація залишається у вигляді колії, а також у миттєвій деформації шини.

Можливість руху, здійснення перевозок та технологічних операцій в умовах слабконесучих опорних поверхонь справляє великий вплив на розвиток економіки та інфраструктури в даних регіонах, де експлуатується автомобіль. Рухатись по опорній основі з низькою несучою спроможністю може тільки транспортний засіб з невеликим тиском рушіїв на грунт.

Ефективність експлуатації вантажних автомобілів у важких дорожніх умовах у великій більшості визначається їхньою прохідністю. Проблема прохідності вантажних автомобілів по опорних поверхнях 3 низькою несучою спроможністю вирішується в основному шляхом удосконалення конструкції рушіїв. У загальному випадку передові світові фірми, які виробляють вантажні автомобілі, до рушіїв висувають такі вимоги ${ }^{2}$ :

- максимальна ефективність (підвищення прохідності та безпечності руху);

Бернацкий В.В. Транспортные машины и транспортно-технологические комплексы. М.: МГТУ «МАМИ», 2005. 48 с.

2 Котляренко В.И., Барахтанов Л.В. Обзор основных типов движителей транспортных средств высокой проходимости. Журнал автомобильных инженеров. № 6, 2016. C. 24-29. 
- універсальність (можливість використання в широкому діапазоні умов експлуатаціi);

- високі тягово-зчіпні якості;

- мінімальні втрати на рух;

- раціональна взаємодія 3 опорною поверхнею с точки зору збереження ії̈ екології;

- якісні показники керованості та стійкості;

- добрі пружні та амортизаційні властивості;

- добра самоочищуваність;

- високі показники міцності та надійності, достатня зносостійкість та довговічність;

- зручність експлуатації (простота та бистрота монтажу, демонтажу та ремонту рушіїв);

- невелика вага та невисока вартість.

Цим вимогам відповідають пневматичні шини, які доповнюють колісний рушій вантажного автомобіля. Пневматичні шини - це одне 3 найбільш простих та ефективніших засобів підвищення прохідності колісних машин. За рахунок варіювання основних параметрів шин (розмірів, форми, кількості шарів, корду, матеріалу, внутрішнього тиску, рисунку та глибини протектора) у широких межах можна змінювати коефіцієнти зчеплення та опору кочення, а також площини контакту між колісним рушієм та опорною поверхнею і, відповідно, тиску на неї. Використання колісних рушіїв дозволяє забезпечити вантажні автомобілі високими швидкостями та високими економічними показниками.

Розвитком пневмоколісних рушіїв у напрямі підвищення прохідності стало створення високоеластичних шин наднизького тиску на базі існуючих широкопрофільних шин. Такі шини наднизького тиску мають тонкостінну резинокордну оболонку з каркасом, який конструктивно складається, як правило, із двох шарів корду, завдяки чому забезпечується іiї висока еластичність. Під час кочення колеса 3 подібною шиною напруження в зоні контакту цієї шини 3 опорною поверхнею розподіляється дуже рівномірно як по довжині, так і по ширині контакту 3 опорною поверхнею, знижуючи граничні навантаження на виступи грунту, та запобігає його руйнуванню.

Під час взаємодії з грунтом така шина не руйнує його поверхню та набуває спроможність (обтікати) нерівності дороги, а виступи та впадини протектора повторюють профіль поверхні дороги, виконують роль грунтозачепів, збільшуючи зчеплення з опорною поверхнею ${ }^{3}$.

${ }^{3}$ Петров Л.М. Теорія оптимізації якісних показників колісного рушія. Труды Одесского политехнического университета. 2010. Вип. 1(33) - 2(34), с. 65-69. 


\section{1. Методика досліджень}

Уявимо автомобільний колісний рушій радіусом $R$, на який припадає гравітаційна вага $G$, i який може обертатися біля горизонтальної осі, перпендикулярної до площини креслення, i проходить через точку $O$. Колесо починає обертатися без початкової кутової швидкості, рис. 1.

Знаходимо кутову швидкість та кутове прискорення кочення колісного рушія автомобіля за горизонтального положення плями контакту - відрізка $A C$.

Уявимо собі, що за обертання автомобільного колісного рушія слід контакту, а тобто відрізок $\frac{A C}{2}$, обертається біля осі х, перпендикулярної до площини креслення (фізичної моделі обертання колісного рушія). При цьому траєкторія точки $A$, яка знаходиться зовні плями контакту, буде рухатись, описуючись радіусом $A C$, i, таким чином, рух точки $A$ буде спрямований у точку $C$.

Знаходимо кутову швидкість автомобільного колісного рушія в момент, коли відрізок $O A_{1}$ складає з вертикальною віссю кут $\varphi$. Для запропонованої фізичної моделі кочення колісного рушія скористуємося теоремою щодо змінення кінетичної енергії механічної системи у формі рівняння.

$$
T-T_{0}=\sum A_{i}^{E}
$$

де $T_{o}=0$, оскільки рух автомобільного колісного рушія почався зі стану спокою.

Швидкості точок колісного рушія в місці контакту з поверхнею за сферичного руху в кожний момент можна розглядати як обертання біля миттєвої осі обертання ${ }^{4}$. Тому кінетична енергія сліду контакту, який безпосередньо знаходиться на шині, здійснює сферичний рух і в даний момент буде визначатися з формули:

$$
T=\frac{1}{2} I_{z} \omega^{2}
$$

Інерційний складник моменту сліду контакту відносно осі $Z$ його обертання в напрямку руху знаходимо з формули: ${ }^{5}$

$$
I_{z}=I_{C z}+m * R^{2}=\frac{m * R}{2}+m * R^{2}=\frac{3}{2} * m * R^{2},
$$

де $m$ - вага, яка діє на слід контакту колісного рушія 3 опорною поверхнею; $\mathrm{R}$ - обертання плями контакту.

${ }^{4}$ Шмидт Г. Параметрические колебания: пер. с нем. Москва: Мир, 1978. 336 с.

${ }^{5}$ Андре Анго. Математика для электро- и радиоинженеров. Москва, 1965, 780 с. 


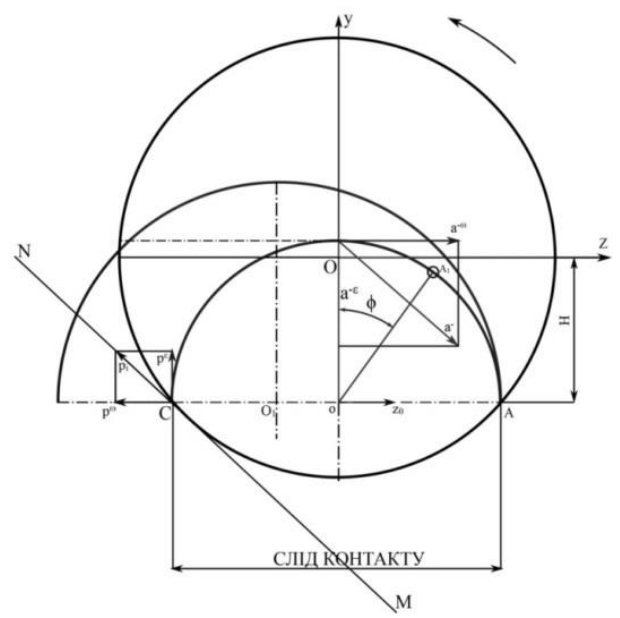

Рис. 1. Фізична модель обертання колеса

\section{2. Результати досліджень}

Для отримання результатів взаємодії автомобільного колісного рушія 3 опорною поверхнею використовуємо попередньо отримані формули (2) i (3).

Для цього підставимо значення інерційного складника моменту сліду контакту відносно осі $Z$ його обертання в напрямку руху $I_{z} 3$ формули (2) у формулу (3). Тоді отримуємо рівняння

$$
T=\frac{3}{4} * m^{*} R^{2} * \omega^{2}=\frac{3}{4} * \frac{G}{g} * R^{2} * \omega^{2},
$$

Під час кочення автомобільного колісного рушія витрачається енергія на подолання сил опору дороги.

Роботу, яка витрачається на подолання сил опору коченню колісного рушія від сили ваги, визначимо за формулою

$$
A_{G}=G^{*} H=G^{*} R^{*}(1-\cos \varphi) \text {, }
$$

де $G$ - сила ваги вантажного автомобіля; $H$ - відстань від опорної поверхні до центру колісного рушія;

Відомо, що за встановленого руху тягового засобу робота рушійних сил дорівнює абсолютній роботі сил опору. На основі цього складаємо рівність із формул (4) та (5), яка показує фізичний процес взаємодії 
кінетичної енергії переміщення контакту колісного рушія та абсолютної роботи на подолання сил опору кочення колісного рушія:

$$
\frac{3}{4} * \frac{G}{g} * R^{2} * \omega^{2}=G^{*} R *(1-\cos \varphi)
$$

3 рівності (формула (6)) отримуємо кутову швидкість обертання сліду контакту:

$$
\omega^{2}=\frac{4}{3} * \frac{g}{R} *(1-\cos \varphi)
$$

а також

$$
\omega=2 \sqrt{\frac{g}{3 R} *(1-\cos \varphi)},
$$

Для отримання кутового прискорення формулу (8) продиференцюємо за часом ${ }^{6}$ :

$$
2 * \omega * \frac{d \omega}{d t}=\frac{2}{3} * \frac{g}{R} * \sin \varphi * \frac{d \varphi}{d t},
$$

Кутове прискорення руху плями контакту колісного рушія 3 опорною поверхнею з формули (9) набуває вигляду:

$$
\varepsilon=\frac{d \omega}{d t}=\frac{2}{3} * \frac{g}{R} * \sin \varphi,
$$

3 метою отримання граничних значень кутових координат руху плями контакту колісного рушія з опорною поверхнею визначимо кутову швидкість сліду контакту $\omega$ та кутове прискорення $\varepsilon$ :

$$
\text { при } \begin{aligned}
\varphi=\frac{\pi}{2} ; \cos \varphi & =0 ; \sin \varphi=1 \\
\omega & =2 \sqrt{\frac{g}{3 R}} ; \varepsilon * \frac{2}{3} * \frac{g}{R} ;
\end{aligned}
$$

Розглянутий випадок відповідає обертанню сліду контакту колісного рушія з опорною поверхнею, яке має площину матеріальної симетрії, біля осі, перпендикулярної до цієї площини. Тоді можна

6 Эльсгольц Л.Э. Дифференциальные уравнения и вариационное исчисления. Москва, 2012. 424 с. 
встановити, що коли осередок сліду контакту не лежить на осі обертання, тоді сили інерції його точок приводяться до рівнодіючої. 3 метою встановлення впливу силових факторів на процес кочення колісного рушія визначимо модулі рівнодіючих обертальних та відцентрових сил інерції точок сліду контакту ${ }^{7}$.

$$
\begin{gathered}
\mathrm{P}^{\mathrm{z}}=\mathrm{m} * \mathrm{a}_{\mathrm{A}}^{\mathrm{z}}=\mathrm{m} * \mathrm{R} * ?=\mathrm{G} / \mathrm{g} * \mathrm{R} * 2 / 3 * \mathrm{~g} / \mathrm{R}=2 / 3 * \mathrm{G} \\
P^{\omega}=m * a_{A}^{\omega}=m^{*} R * \omega^{2}=\frac{G}{g} * R * \frac{4}{3} * \frac{g}{R}=\frac{4}{3} * G,
\end{gathered}
$$

Вектори сил $P^{\varepsilon}$ та $P^{\omega}$ будуть направлені протилежно обертальному та центроспрямованому прискоренням центра ваги сліду контакту $a^{\omega}$ та $a^{\varepsilon}$.

Приймемо припущення, що лінія $N M$ являється лінією дії рівнодіючої сил інерції $P_{i}$. Прикладемо цю силу в точці $K$, яка знаходиться на горизонтальному шляху, по якому обертається колісний рушій.

Прикладемо до сліду контакту колісного рушія з опорною поверхнею силу ваги $\bar{G}$. Замінимо дію опорної поверхні центру сліду контакту на колісний рушій реакцією, розклавши іiі на складники: $Y_{0}^{-}$та $Z_{0}^{-}$. Для визначення цих складників по принципу Германа - Ейлера Д'Аламбера складемо для плоскої системи сил $G^{-}, Y_{0}^{-}, Z_{0}^{-}, P, P$ які діють на колісний рушій, рівняння проекцій на осі $Y$ та $Z:^{8}$

$$
\sum Y_{i}=0 ; Y_{0}-P^{\omega}=0
$$

Відкіля $Y_{0}=P^{\omega}=\frac{4}{3} * G$

$$
\sum Z_{i}=0 ;-G+Z_{0}+P^{\varepsilon}=0,
$$

Відкіля

$$
Z_{0}=G-P^{z}=\frac{1}{3} * G
$$

${ }^{7}$ Санкин Ю.Н., Гурьянов М.В. Частотный метод оценки курсовой устойчивости автомобиля на основе его моделей в виде систем со многими степенями свободы и нелинейным взаимодействием шин с дорожным покрытием / под общ. ред. Ю.Н. Санкина. Ульяновск: УЛГТУ, 2011. 243 с.

8 Жилейкин М.М., Захаров А.Ю., Паньшин М.В. Проверка адекватности и точности математической модели взаимодействия эластичного колеса с деформируемым опорным основанием. Труды НГТУ им. Р.Е. Алексеева. 2018. № 4 (123). 
Модуль рівнодіючої сил інерції знайдемо з рівняння

$$
P_{i}=\sqrt{\left(P^{\varepsilon}\right)^{2}+\left(P^{\omega}\right)^{2}}=\frac{2}{3} * G * \sqrt{5}
$$

На рис. 2 наведена схема контакту колісного рушія 3 опорною поверхнею.

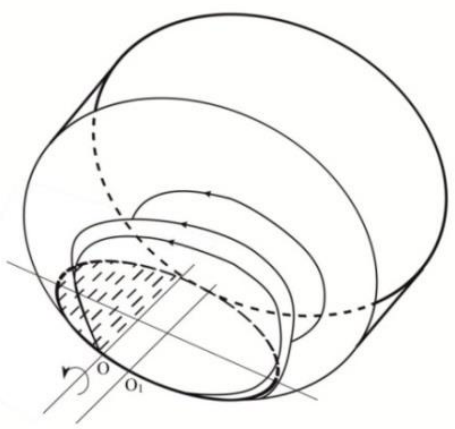

Рис. 2. Схема контакту колісного рушія з опорною поверхнею

Згідно 3 рис. 2 слід контакту являє собою фігуру, наближену до еліпса з полюсами $a$ та $b$, що відображено на рис. 3 .

Величину головного моменту сил інерції відносно точки $O_{1}-$ осі $X$ визначимо з формули.

$$
M^{P i}=I_{x}^{*} \varepsilon,
$$

де $I_{x}$ - момент інерції еліпса відносно осі $X$; $\varepsilon$ - кутове прискорення.

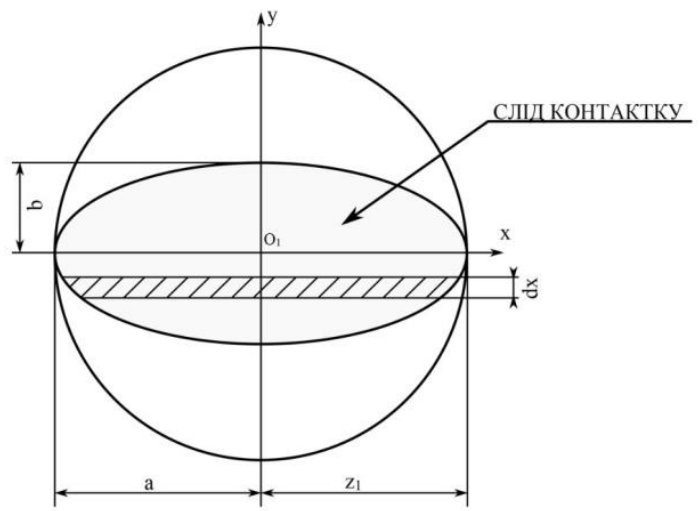

Рис. 3. Геометрична схема сліду контакту 
Представимо момент інерції плями контакту, яку приводимо до вигляду еліпса як суму моментів інерції елементарних прямокутників висотою $Z$ та шириною $d x$ :

$$
I_{x}=\int_{F} \frac{Z^{3} d x}{12}=\frac{b^{3}}{a^{3}} * \int_{F} \frac{Z_{i}^{3} d x}{12}
$$

Інтеграл у формулі (15) являє собою момент інерції кола радіуса $\mathrm{R}$ відносно осі $X$ і який під час кочення колеса перетворює слід контакту в «згусток тягнучої енергії». Цей момент інерції дорівнює

$$
I_{x k}=\frac{\pi b^{4}}{4} \text { чи } I_{x k}=\frac{3}{2} * \frac{G}{g} * R^{2},
$$

де $R=b$.

Величина головного моменту сил інерції деформованої частини шини відносно точки $O$, сліду контакту, буде знайдено зі значенням моменту інерції згідно з формулою (14)

$$
M^{P i}=\frac{b^{3}}{a^{3}} * \frac{3}{2} * \frac{G}{g} R^{2} * \varepsilon=\frac{b^{3}}{a^{3}} * \frac{3}{2} * \frac{G}{g} R^{2} * \frac{2}{3} * \frac{g}{R} * \sin \varphi,
$$

де $a$ - ширина сліду контакту; $b$ - довжина сліду контакту.

Для механічної системи вантажного автомобіля, у відсутності деформування колісного рушія витримується рівняння:

$$
M^{P_{i}}+M_{0}=0
$$

За великої деформації рівняння перетворюється у вигляд:

$$
\left|\mathrm{M}^{\left(\mathrm{P}_{\mathrm{i}}\right)}\right| \neq \mathrm{M}_{0}^{\mathrm{P}}=\mathrm{G} * \mathrm{R}
$$

Рівняння (19) буде виконуватися за умови, коли кут $\varphi=\frac{\pi}{2}$ та пляма контакту стиснутої шини буде обертатись, як кругле тіло.

Відстань від точки $O$ до лінії дії сили інерції $P^{i}$ знайдемо за формулою:

$$
h=\frac{\left|M^{P_{i}}\right|}{P^{I}}=\frac{\frac{b^{3}}{a^{3}} * \frac{3}{2} * \frac{G}{g} * b^{2} * \sin \varphi}{\frac{2}{3} * G \sqrt{5}}=\frac{3}{2} * \frac{1}{\sqrt{5}} * \frac{b^{3}}{a^{3}} * \frac{b^{2}}{R} * \sin \varphi
$$


Згідно з формулою (2) кінетична енергія, яка реалізується слідом контакту, остаточно буде мати вигляд:

$$
\begin{gathered}
T=\frac{1}{2} * \frac{3}{2} * \frac{G}{g} * b^{2} *\left(2 \sqrt{\frac{g}{3 R}}(1-\cos \varphi)\right)^{2}= \\
=\frac{3}{4} * \frac{G}{g} * b^{2} * 4 * \frac{g}{3 R}(1-\cos \varphi)= \\
=\frac{G}{g} * \frac{b^{2}}{R} *(1-\cos \varphi)
\end{gathered}
$$

Схема щодо виконання процесу з ефекту тягнучого пузиря наведена на рис. 4.

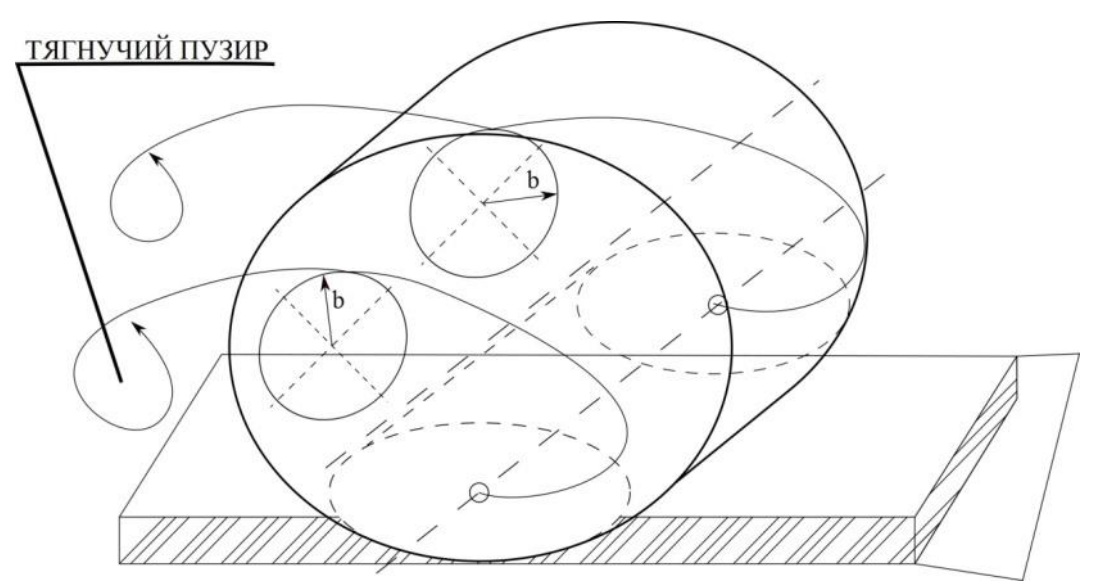

Рис. 4. Схема виконання процесу ефекту тягнучого пузиря

\section{3. Графічне відображення результатів дослідження}

3.1. Залежність зміни кінетичної енергії від одночасної зміни кута та поздовжньої осі плями контакту колісного рушія з опорною поверхнею

На рисунку 5 показано залежність зміни кінетичної енергії від одночасної зміни кута повороту плями контакту відносно ії̈ осередку та поздовжньої осі плями контакту колісного рушія 3 опорною поверхнею. 


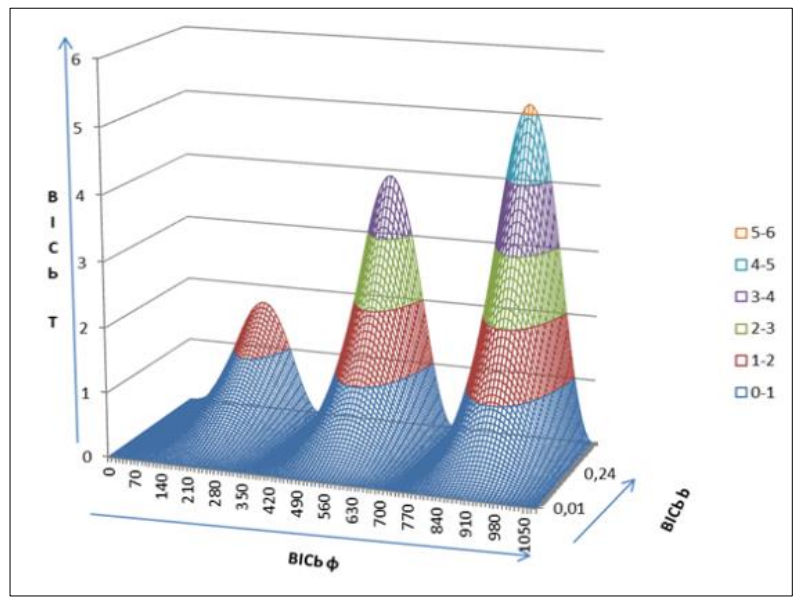

Рис. 5. Залежність зміни кінетичної енергії від одночасної зміни кута повороту плями контакту відносно її осередку та поздовжньої осі плями контакту колісного рушія з опорною поверхнею

\section{2. Залежність кінетичної енергії від кута та сили ваги}

На рисунку 6 показано залежність зміни кінетичної енергії від одночасної зміни кута повороту плями контакту відносно ії осередку та сили ваги вантажного автомобіля, яка приходиться на колісний рушій.

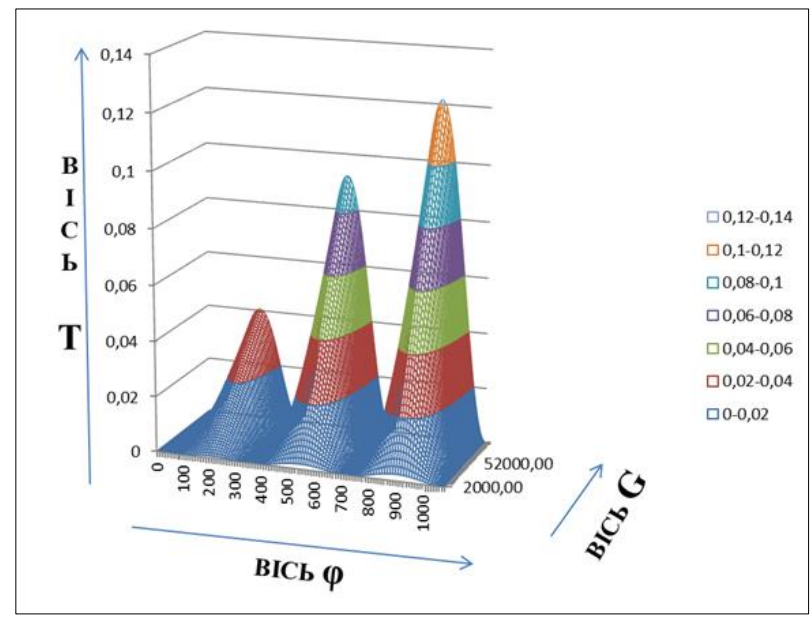

Рис. 6. Залежність зміни кінетичної енергії від одночасної зміни кута повороту плями контакту відносно ії осередку та сили ваги вантажного автомобіля, яка приходиться на колісний рушій 
3.3. Залежність зміни кінетичної енергії від одночасної зміни кута повороту плями контакту та радіуса кочення плями контакту

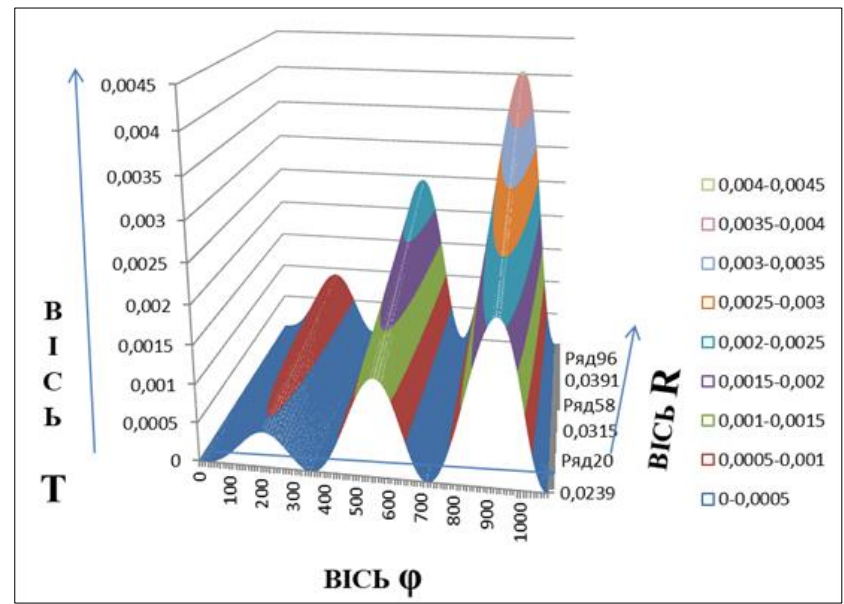

Рис. 7. Залежність зміни кінетичної енергії від одночасної зміни кута повороту плями контакту відносно їі осередку та зовнішнього радіуса прокручення плями контакту відносно їі осередку

3.4. Залежність зміни відстані $\mathrm{h}$ від зміни кута повороту плями контакту та поздовжньої осі плями контакту

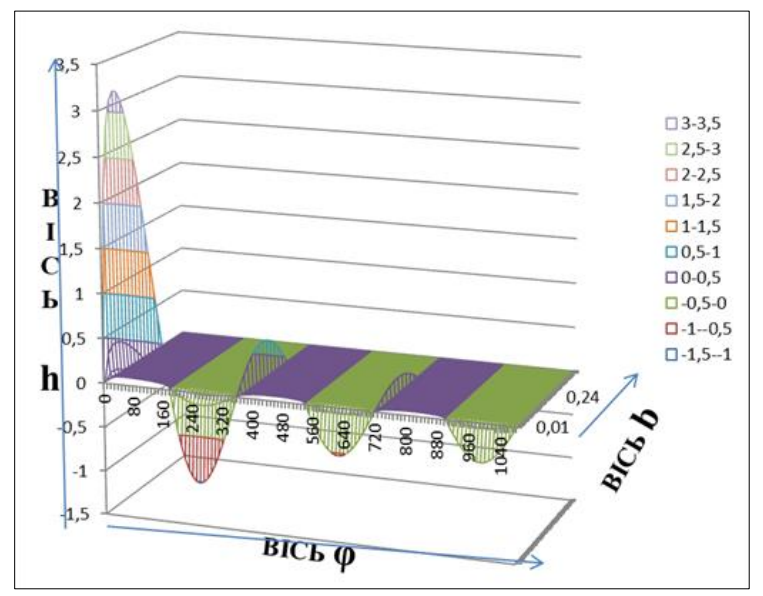

Рис. 8. Залежність зміни відстані h точки $O$ до лінії дії сили інерції $Р$ від зміни кута $\varphi$ повороту плями контакту відносно ії осередку та поздовжньої осі b плями контакту колісного рушія з опорною поверхнею 


\section{5. Залежність зміни відстані h від зміни кута поперечної осі а}

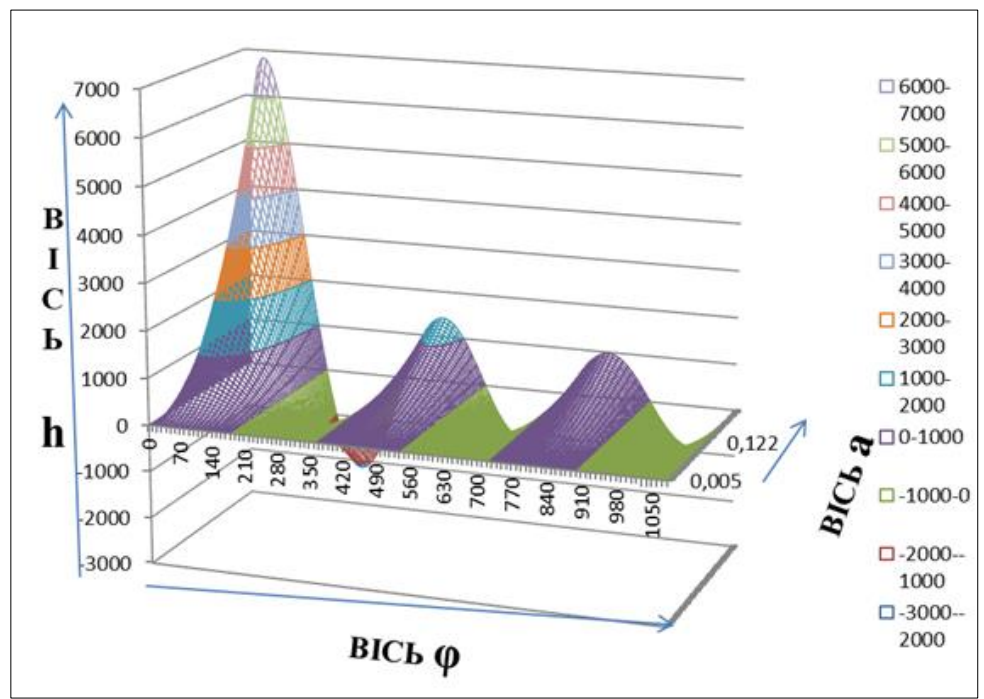

Рис. 9. Залежність зміни відстані һ точки $O$ до лінії дії сили інерції $P$ від зміни кута $\varphi$ повороту плями контакту відносно їі осередку поперечної осі а плями контакту колісного рушія з опорною поверхнею

\section{ВИСНОВКИ}

У публікації розглянуто динаміку руху плями контакту взаємодії колісного рушія вантажного автомобіля з опорною поверхнею.

Процес переміщення вантажного автомобіля можна підпорядкувати процесу кочення безпосередньо плямі контакту.

Розроблено математичну модель кочення плями контакту колісного рушія вантажного автомобіля з використанням диференційних рівнянь впливу змінних параметрів на кінетичну енергію всього.

Виявлена зона найбільш ефективної роботи кочення колісного рушія за допомогою обертального руху плями контакту.

Виявлено можливість створення теоретичного макету колісного рушія з використанням руху плями контакту.

Альтернативним джерелом енергії для колісних рушіїв вантажних автомобілів може бути використана енергія, яка накопичується в зоні плями контакту, а потім із зони плями контакту використовується в деформованих частинах шини колісного рушія (як механічна енергія), та перетворення іiі в потенціальну енергію і зворотно в кінетичну енергію руху всієї конструкції вантажного автомобіля. 


\section{АНОТАЦІЯ}

У публікації розглянуто динаміку руху плями контакту взаємодії колісного рушія вантажного автомобіля 3 опорною поверхнею, що дозволяє процес переміщення вантажного автомобіля підпорядкувати процесу кочення безпосередньо плями контакту. Із цією метою була запропонована фізико-математична модель руху плями контакту колісного рушія вантажного автомобіля.

Розроблено математичну модель кочення плями контакту колісного рушія вантажного автомобіля з використанням диференційних рівнянь впливу змінних параметрів на кінетичну енергію всього. Розрахунки та графічні залежності виконувались у середовищі «Ехcel». Результати за цими розрахунками показали зону найбільш ефективної роботи кочення колісного рушія за допомогою обертального руху плями контакту.

У роботі розглянуто можливість створення теоретичного макету колісного рушія з використанням руху плями контакту, рух якої забезпечує додаткову кінетичну енергію. Альтернативним джерелом енергії для колісних рушіїв вантажних автомобілів може бути використана енергія, яка накопичується в зоні плями контакту, а потім iз зони плями контакту використовується в деформованих частинах шини колісного рушія (як механічна енергія), та перетворення іiі в потенціальну енергію i зворотну кінетичну енергію руху всієї конструкції вантажного автомобіля.

\section{ЛІТЕРАТУРА}

1. Бернацкий В.В. Специализированный подвижной состав грузового автотранспорта : учебное пособие для студентов вузов, обучающихся по специальности «Автомобиле- и тракторостроение» направления подготовки дипломированных специалистов «Транспортные машины и транспортно-технологические комплексы». Москва : МГТУ «МАМИ», 2005. 48 с.

2. Андре Анго. Математика для электро- и радиоинженеров. Москва, 1965. $780 \mathrm{c}$.

3. Петров Л.М. Теорія оптимізації якісних показників колісного рушія Труды Одесского политехнического университета. 2010. Вып. 1 (33). № 2 (34). С. 65-69.

4. Шмидт Г. Параметрические колебания : пер. с нем. Москва : Мир, 1978. 336 с.

5. Санкин Ю.Н., Гурьянов М.В. Частотный метод оценки курсовой устойчивости автомобиля на основе его моделей в виде систем с многими степенями свободы и нелинейным взаимодействием шин с 
дорожным покрытием / под общ. ред. Ю.Н. Санкина. Ульяновск : УЛГТУ, 2011.243 с.

6. Эльсгольц Л.Э. Дифференциальные уравнения и вариационное исчисления. Москва, 2012. 424 с.

7. Жилейкин М.М., Захаров А.Ю., Паньшин М.В. Проверка адекватности и точности математической модели взаимодействия эластичного колеса с деформируемым опорным основанием. Tpyды НГТУ им. Р.Е. Алексеева. 2018. № 4 (123).

8. Котляренко В.И., Барахтанов Л.В. Обзор основных типов движителей транспортных средств высокой проходимости. Журнал автомобильных инженеров. 2016. № 6. С. 24-29.

\section{Information about the authors:}

Petrov L. M.,

Candidate of Technical Sciences, Associate Professor,

Odessa Military Academy

21, First Station str., Odesa, 65009, Ukraine

Skorychenko O. I., Teacher, Project team leader, Odessa Military Academy 4a, Artiliriyska str., Odesa, 65000, Ukraine 